\title{
PENGARUH TINGKAT PENDIDIKAN TERHADAP PENINGKATAN KINERJA PEGAWAI PADA BADAN KESATUAN BANGSA DAN POLITIK PROVINSI SULAWESI SELATAN
}

\section{THE EFFECT OF EDUCATION LEVEL ON IMPROVING EMPLOYEE PERFORMANCE IN THENATIONAL UNITY, POLITICS AND COMMUNITY AGENCY OF SOUTH SULAWESI PROVINCE}

\author{
Maulana Muhammad ${ }^{1}$ Jessica F. Tonapa ${ }^{2}$ \\ ${ }^{1}$ Program Studi Sarjana Terapan MSDM Aparatur Politeknik STIA LAN Makassar \\ email : maulanamuhammad179@yahoo.com \\ ${ }^{2}$ Politeknik STIA LAN Makassar \\ email : jessica.tonapa@gmail.com
}

\begin{abstract}
ABSTRAK
Pencapaian prestasi kinerja pegawai Badan Kesbangpol Provinsi Provinsi Sulawesi Selatan pada kurun 3 tahun terakhir menunjukkan presentase yang tidak terlalu stabil dimana faktor tingkat pendidikan jajaran pegawai yang beragam menjadi hal yang perlu untuk diperhatan. Pada tahun 2017 dan 2018 presentase capaian kinerja berkategori cukup tinggi sedangkan pada tahun 2019 berkategori sedang. Tujuan penelitian ini ialah untuk mengetahui pengaruh tingkat pendidikan terhadap peningkatan kinerja pegawai. Metode Kuantitatif digunakan pada penelitian ini dengan tipe asosiatif untuk mengetahui pengaruh antara dua variabel. Data dikumpulkan melaluikuesioner,observasi dan dokumentasi. Sampel dalam penelitian ini adalah keseluruhan populasi penelitian, dan jumlah sampel yang menggunakan teknik sampling jenuh sebanyak 48 responden. Dalam penelitian ini teknik analisis data yang digunakan ialah analisis regresi linear sederhana, uji prasyarat analisis dan pengujian hipotesis. Hasil penelitian menunjukkan bahwa tingkat pendidikan berpengaruh positif dan signifikan terhadap peningkatankinerja pegawai dengan presentase sebesar $24 \%$. Kecakapan intelektual yang diperoleh dari jenjang pendidikan sebaiknya juga diiringi dengan adanya upaya lain seperti pengembangan kompetensi dalam menunjang peningkatan kinerja.
\end{abstract}

Kata Kunci : Pengaruh, Tingkat Pendidikan, Peningkatan Kinerja

\section{ABSTRACT}

The achievement of the employee performances of the National and Political Unity Agency of South Sulawesi Province in the last 3 years shows a percentage that is not very stable where the educational level factor of the various staffs needs to be considered. In 2017 and 2018 the percentage of performance achievements was categorized quite high, while in 2019 it was in the medium category. The objective of this research was to determine the influence of educational level on improving employee performance. This study used a quantitative type with associative research to determine the effect between two variables. Data were collected through questionnaries, observation and documentation. The sample of this study was the entire study population that consist of 48 people with a saturated sampling technique. The technique of data analysis applied simple linear regression 
analysis, pre-test reqruitments analysis and hypothesis test. The result showed that the level of education had a positive and significant effect to improving employee performance with a percentage of $24 \%$. The Intellectual skills obtained from the education level should be accompanied by other efforts such as competency development in supporting performance improvement.

Keywords: Influence, Education Level, Performance Improvement

\section{PENDAHULUAN}

Aset yang paling berharga dalam sebuah organisasi adalah sumber daya manusia dan asset tersebut tentu dibutuhkan pengelolaan yang baik. Sumber daya manusia adalah bagian terpenting yang memainkan peran penting dalam suatu organisasi, karena sumber daya manusia adalah bagian dari manajemen, manajemen dan motivasi organisasi untuk mencapai tujuan. Sumber daya manusia merupakan faktor terpenting yang berperan aktif dalam suatu organisasi. Oleh karena itu sumber daya manusia harus dikelola dengan baik untuk meningkatkan efektivitas dan efisiensi organisasi.

Hal tersebut mengisyaratkan bahwa SDM harus mampu berperan aktif dan berperan sebagai pemimpin dalam kegiatan organisasi, karena sebagai sumber daya harus mampu menjadi perencana, partisipan dan determinan pencapaian tujuan organisasi. Tanpa partisipasi aktif organisasi, tujuan tidak dapat tercapai. Sekalipun organisasi memiliki peralatan canggih, peralatan kompleks tidak terlalu berguna bagi perusahaan. Jika tidak termasuk dalam fungsi aktivitas pegawai maka akan sulit untuk mengatur orang, karena heterogen pemikiran, perasaan, keadaan, keinginan dan sejarah yang dihadirkan kepada organisasi maka harus ada sistem yaitu pengelolaan SDM. Perkembangan suatu organisasi tergantung pada kualitas sumber daya manusia, oleh karena itu kualitas dari SDM menjadi faktor utama yang dibutuhkan oleh organisasi untuk mencapai tujuannya.

UU No. 5 tahun 2014 mengenai ASN (Aparatur Sipil Nasional) pada ayat 1 \& 5, Pengelolaan Sumber Daya Perangkat merupakan proses ASN untuk menghasilkan nilai dasar, etika profesi, bebas dari campur tangan politik, jaringan korup, kolusi dan nepotisme pegawai ASN profesional. Dalam perkembangannya saat ini, sumber daya manusia juga dianggap memiliki peran yang penting, termasuk sumber daya manusia yang sangat potensial untuk berperan sebagai modal dalam organisasi. Jika organisasi itu ada 
maka dapat terwujud sebagai nyata dan tidak berwujud. potensi. Faktor manusia dalam suatu organisasi sangat krusial dalam pencapaian tujuan organisasi itu sendiri. Sumber daya manusia merupakan sumber daya paling melimpah yang harus dikelola secara efektif karena sumber daya manusia merencanakan, mengatur, dan menggunakan sumber daya lain. Sumber daya manusia apabila tidak termanfaatkan dengan baik dan secara efektif, semua orang tidak akan dapat memperoleh manfaat dari banyak organisasi (Nasution, 2010: 2). Manusia apabila dibahas merupakan hal yang sangat kompleks untk diperbincangkan dalam sebuah organisasi, dalam bentuk apapun (Arep dan Tanjung, 2003: 1). Dalam suatu organisasi keberadaan SDM adalah hal yang vital sebab dapat berkontribusi terhadap efektivitas dalam berorganisasi. SDM disini dapat digunakan untuk mengontrol teknik, penggunaan modal, pengawasan modal, dan produksi produk atau layanan berkualitas.

Dalam organisasi yang mementingkan diri sendiri, peran masyarakat semakin dipercaya sebagai sumber daya, sehingga mendorong berkembangnya pengetahuan tentang cara menggunakan sumber daya manusia untuk mencapai kondisi yang optimal. Flippo menjabarkan dalam Fathoni (2006: 26) bahwa Manajemen sumber daya manusia adalah perencanaan, pengorganisasian, pembinaan dan pemantauan akuisisi, pengembangan, pemberian layanan, integrasi, pemeliharaan dan pemisahan sumber daya manusia untuk mencapai tujuan akhir, organisasi dan masyarakat.

Kinerja seorang karyawan yang rendah tercermin dalam banyak aspek, antara lain tujuan organisasi, evaluasi kinerja karyawan yang rendah, dan rendahnya tingkat bantuan dari karyawan itu sendiri. Karyawan adalah salah satu elemen paling dinamis, posisinya tidak dapat disamakan dengan elemen lainnya (Hasibuan, 2007: 76). Hasil pekerjaan dan prestasi menggambarkan kondisi sumber daya manusia (SDM) yang mumpuni. Kinerja yang baik dalam kerangka kerja profesional adalah bagaimana seseorang menunjukkan perilaku kerja yang mengarah pada tujuan organisasi, misalnya, bagaimana mengelola sumber daya pendukung yang tersedia untuk mencapai hasil kerja yang baik.

Kinerja seseorang adalah hasil pemikiran dan energi karyawan. Pekerjaan yang dilakukan dapat nyata, terlihat, dan terukur, namun dalam banyak hal, hasil pemikiran dan energi tidak dapat dianggap sebagai pemikiran dan inovasi seseorang 
itu sendiri untuk meningkatkan kemajuan organisasi. Mangkunegara (2006: 67) meyakini bahwa kinerja merupakan hasil dari kualitas kerja dan pencapaian karyawan dalam melaksanakan tugasnya. Tingkat pendidikan merupakan indikator organisasi yang menentukan pekerjaan. Sebagaimana kita ketahui bersama, jika karyawan memiliki pekerjaan yang berkualitas dan jumlahnya banyak untuk menjalankan tugasnya, maka kinerjanya juga baik (Mangkunegara, 2006: 67). Kinerja yang baik akan berkontribusi pada pembangunan berkelanjutan perusahaan. Sebaliknya, output yang rendah akan menurunkan efisiensi sehingga merusak keberlangsungan perusahaan (Supratikno, 2006: 13). Penilaian kinerja karyawan sangat penting untuk meningkatkan kinerja organisasi. Pada dasarnya, evaluasi kinerja karyawan membutuhkan beberapa aspek.

Penilaian kinerja karyawan yang dilakukan menurut Mangkunegara (2006: 67) meliputi : (1) Mutu kerja adalah mutu pekerjaan berdasarkan Standar yang ditetapkan biasanya diukur dengan akurasi, ketelitian, keterampilan, dan keberhasilan pekerjaan. (2) Jumlah posisi adalah banyaknya posisi berdasarkan jam kerja saat ini. (3) Disiplin di tempat kerja adalah karyawan harus menaati disiplin, tanggung jawab dan mematuhi aturan. (4) Inisiatif ialah kompetensi untuk menemukan problematika dan mengambil tindakan korektif, memberikan saran untuk perbaikan, dan bertanggung jawab untuk menyelesaikan tugas yang tidak ditugaskan. (5) Tanggung jawab diberikan setelah memperhatikan kebijakan, pekerjaan, peralatan dan infrastruktur yang digunakan karyawan, dan perilaku kerja.

Ini bisa menjadi dua indikator tingkat pendidikan, termasuk tingkat pendidikan (dasar, menengah, hingga tinggi) dan sektor berkualitas (Dewi dkk, 2016: 3). "UU No.20 Tahun 2003 tentang Sistem Pendidikan Nasional" Jenjang pendidikan yang ditetapkan adalah jenjang pendidikan yang ditentukan sesuai dengan tingkat perkembangan peserta didik, tujuan yang ingin dicapai, dan perkembangan keterampilan. Ada dua jenjang pendidikan, formal dan informal. Jenjang pendidikan formal sesuai dengan ketentuan Bab 14, $\mathrm{Bab}$ 6, Bab 20 tahun 2003, yaitu pendidikan dasar, pendidikan menengah, dan pendidikan tinggi.

Pendidikan berfungsi mendorong dan mendorong kapabilitas sumber daya manusia potensial untuk meningkatkan prestasi kerja, dan dapat mendorong karyawan untuk bersaing memperebutkan nilai melalui pendidikan. Pendidikan merupakan salah satu indikator 
kemampuan seseorang dalam menyelesaikan pekerjaan, dan pendidikan adalah tingkat resmi yang diterima seseorang selama periode pendaftaran." Indikator tingkat pendidikan meliputi tingkat pendidikan dan departemen yang memenuhi syarat. Tingkat pendidikan merupakan tahapan pendidikan yang ditentukan oleh tingkat perkembangan peserta didik, tujuan yang ingin dicapai, dan kemampuan untuk berkembang. Sebelum merekrut karyawan terlebih dahulu, penerapan departemen, perusahaan akan menganalisa tingkat pendidikan dan penerapan departemen pendidikan karyawan untuk menempatkan mereka pada posisi yang sesuai untuk pendidikan mereka. Orang yang berlatar belakang pendidikan dianggap kompeten untuk posisi tertentu. Karena seseorang berada dalam lingkungan keluarga maka tingkat pendidikannya pun berkelanjutan. Pendidikan formal dimulai ketika seseorang masuk sekolah dasar hingga universitas.

Menurut Notoatmodjo, (2003: 53), dimensi tingkat pendidikan meliputi: (1) Jenjang pendidikan, yaitu suatu tahapan dimana pendidikan yang ditentukan oleh tingkat perkembangan seseorang, hingga pada aspek tujuan dan keterampilan yang ingin dicapai. perkembangan dari. (2)
Integrasi departemen Pertama, proses departemen sebelum merekrut karyawan. Organisasi terkait akan menganalisis tingkat pendidikan karyawan dan kesesuaian departemen pendidikan karyawan, kemudian menempatkannya pada posisi sesuai dengan tingkat pendidikan Anda. skor. (3) Keterampilan bersaing adalah pengetahuan, area kerja, keterampilan dan nilai inti yang tercermin dalam kebiasaan perilaku. Menurut Tyson and Jackson dalam Mangkunegara (2006 : 78) peningkatan kinerja merupakan suatu konsep sederhana tetapi penting. Konsep tersebut didasarkan pada ide bahwa sebuah tim akan meningkat dengan cepat dan terus-menerus dengan cara meninjau keberhasilan dan kegagalannya.

Tyson dan Jackson mengatakan ada 4 (empat) tahap dalam rencana untuk meningkatkan kinerja, yaitu : Tahap 1, memulai tugas-tugas yang telah dikerjakan oleh kelompok dan membiarkan tim mengidentifikasi faktor-faktor signifikan yang telah memberikan kontribusi terhadap keberhasilan dan tugas-tugas yang merintangi keberhasilan. Tahap 2, dari faktor-faktor keberhasilan dan kegagalan pilihlah yang praktis dan buang yang tidak mempunyai nilai. Tahap 3, kelompok kemudian harus menyetujui bagaimana membuat faktor-faktor tersebut 
dengan tepat dan menyingkirkan yang lain. Tahap 4, analisis tersebut tidak hanya dilakukan pada tingkat kelompok, tetapi juga pada tingkat individual. Kinerja pada umumnya terdiri dari kinerja pada tingkat organisasi dan pada tingkat individu. Pada tingkat organisasi, kinerja yang kurang berkualitas merupakan akibat atau hasil dari kepemimpinan yang kurang berkualitas, manajemen yang kurang profesional, atau sistem kerja yang tidak baik. Untuk mencapai peningkatan kinerja yang berkualitas dan mengatasi masalah yang ditemui dalam upaya meningkatkan kinerja.

Schaffer dalam Sudarmanto (2009:46) memberikan beberapa strategi, yaitu : (1) Seleksi tujuan mengatasi masalah yang paling urgen lebih dahulu, mengoreksi biaya yang terlalu tinggi, spesifikasi kualitas yang rendah, target kerja yang tidak tercapai, memastikan masalah-masalah tersebut diatasi dengan tuntas. (2) Spesifikasi hasil yang diharapkan: sasaran harus SMART (Specific, Measurable, Achievable, Realistic, Time-bound). (3) Komunikasi yang jelas. (4) Alokasi tanggung jawab, organisasi perlu membagi atau mengalokasikan tanggung jawab untuk mencapai tujuan setiap karyawan. (5) Luas proses, sukses dalam mencapai tujuan dapat digunakan untuk mengulangi proses dengan tujuan yang baru atau perluasan tujuan yang terdahulu.

Kemudian indikator kinerja pegawai yang dirumuskan menurut Sudarmanto (2009: 11) adalah kualitas kerja, inisiatif (kecepatan), inisiatif (Prakarsa), kemampuan (kemampuan menyelesaikan pekerjaan sesuai standar), dan komunikasi (komunikasi). Peraturan Daerah Provinsi Sulawesi Selatan (No. 10 tahun 2016), pembinaan dan pengawasan perangkat daerah, Satuan Nasional dan Lembaga Politik Provinsi Sulawesi Selatan dan Selatan telah menyusun dan mengatur kebijakan daerah di bidang satuan nasional dan politik. dalam standar transisi Peran implementasi didasarkan pada prinsip desentralisasi, dan tugas-tugas administrasi. Badan Kesbangpol Provinsi Sulawesi Selatan, yang adalah salah satu instansi pemerintah atau perpanjangan tangan dari pemerintah pusat yang mengikuti perubahan dan perkembangan di era Revolusi Industri 4.0, tentunya perlu dilakukan optimalisasi kinerja setiap pegawai. Peneliti melakukan observasi awal di Badan Kesatuan Bangsa dan Politik Provinsi Sulawesi Selatan selama proses "magang" dilokasi tersebut. Dimana penulis mendapatkan data observasi awal. 
Maulana Muhammad dan Jessica F. Tonapa / Jurnal Administrasi Negara, V27 - 01

(2021) / 49-69

Berikut uraian terkait data tingkat pendidikan pegawai :

Tabel 1

Tingkat Pendidikan Pegawai

Kesbangpol Prov. Sulawesi Selatan

\begin{tabular}{clc}
\hline No & Jenjang Pendidikan & $\begin{array}{c}\text { Jumlah } \\
\text { (Orang) }\end{array}$ \\
\hline 1 & Doktor (S3) & 1 \\
2 & Magister (S2) & 9 \\
3 & Strata 1 (S1) & 27 \\
4 & Diploma & 3 \\
5 & SMA Sederajat & 8 \\
\hline & Jumlah & 48 Orang \\
\hline
\end{tabular}

Sumber : Data Primer (diolah 2020)

Kemudian berdasarkan uraian dari tabel diatas, dapat dilihat bahwa mayoritas Pegawai Badan Kesatuan Bangsa dan Politik Provinsi Sulawesi Selatan memiliki tingkat pendidikan Strata 1 (S1) dengan presentase $56.25 \%$, berpendidikan Magister (S2) dengan presentase 18.75\%, Diploma dengan presentase $6.25 \%$, SMA sederajat dengan presentase $16.67 \%$ dan hanya Kesbangpol yang berpendidikan Doktor. Selanjutnya pada tabel 2, juga dijabarkan mengenai kondisi capaian penilaian Prestasi Kerja Pegawai pada tabel dan grafik penilaian prestasi kerja berdasarkan tingkat Pendidikan.

Capaian penilaian prestasi kinerja pegawai Badan Kesbangpol Provinsi SulSel pada kurun waktu 3 tahun terakhir menunjukkan presentase yang tidak terlalu stabil dimana pada tahun 2017 dan 2018 presentase berkategori cukup tinggi sedangkan pada tahun 2019 berkategori sedang.

Tabel 2

Penilaian Prestasi Kerja

\begin{tabular}{|c|c|c|c|c|}
\hline \multirow{2}{*}{ No } & \multirow{2}{*}{ Tahun } & \multicolumn{2}{|c|}{ SKP (\%) } & \multirow{2}{*}{ Ket. } \\
\hline & & Org & $\%$ & \\
\hline 1 & 2017 & 50 & 86.2 & $\begin{array}{l}\text { Cukup } \\
\text { Tinggi }\end{array}$ \\
\hline 2 & 2018 & 48 & 80.1 & $\begin{array}{l}\text { Cukup } \\
\text { Tinggi }\end{array}$ \\
\hline 3 & 2019 & 48 & 78.3 & Sedang \\
\hline
\end{tabular}

Sumber : Data Primer (Diolah 2020)

Kemudian apabila ditinjau berdasarkan tingkat pendidikan, pegawai yang memiliki tingkat pendidikan S1-S3 lebih mendominasi dalam presentase capaian penilaian kinerja dibanding dengan yang hanya berpendidikan Diploma-SMA. Karena pada dasarnya, peningkatan kinerja pegawai tidak terlepas dari faktor tingkat pendidikan. Lebih lanjut kemudian peneliti tertarik untuk melakukan pengkajian lebih dalam agar mengetahui pengaruh tingkat pendidikan terhadap peningkatan kinerja pegawai ditambah dengan kondisi keberagaman tingkat pendidikan pegawai Badan Kesbangpol Provinsi Sul-Sel sehingga peneliti tertarik untuk melakukan peninjuan lebih dalam.

\section{METODE PENELITIAN}

Penelitian ini menggunakan metode kuantitatif, metode penelitian yang 
didasarkan pada filosofi positivis dan digunakan untuk menguji populasi atau sampel tertentu. Alat penelitian digunakan untuk mengumpulkan data. Analisis data adalah kuantitatif / statistik untuk menguji hipotesis. Selain itu jenis penelitian dari penelitian ini adalah terkait, dan distribusinya untuk mengetahui pengaruh antara kedua variabel yang terdapat pada penelitian. Dalam penelitian ini, metode korelasi digunakan untuk mengetahui pengaruh antara dua variabel dalam penelitian ini. Dalam penelitian ini, metode korelasi digunakan untuk mengetahui pengaruh tingkat pendidikan terhadap peningkatan kinerja pegawai.

Dalam penelitian ini, analisis regresi linear sederhana digunakan untuk mengetahui pengaruh variabel independen (X) dan variabel dependen (Y). Kemudian karena adanya kebutuhan akan pengumpulan data penelitian maka peneliti mengumpulkan Data diperoleh dari alat penelitian berupa wawancara, hasil observasi dan survei. Sampel dalam penelitian ini adalah seluruh populasi dalam penelitian ini dengan menggunakan teknik sampling jenuh yang berjumlah 48 orang. Data hasil penelitian yang diperoleh melalui tahapan pengujian validitas dan reabilitas dengan teknik analisis data pada penelitian adalah analisis regresi linear sederhana untuk memprediksi atau menguji pengaruh satu variabel bebas atau variabel independent terhadap variabel terikat atau variabel dependen. Apabila skor variabel bebas diketahui, maka skor variabel terikatnya dapat diprediksi besarnya. Analisis regresi juga dapat dilakukan untuk mengetahui linearitas variabel terikat dengan variabel bebasnya.

Selanjutnya berlanjut untuk melalui tahap uji pra syarat analisis yang mencakup uji normalitas dan uji linearitas. Pengujian hipotesis yang dilakukan dengan uji signifkansi parsial (uji-t) untuk mengetahui ada tidaknya pengaruh dari variabel penelitian dan analisis koefisien determinasi digunakan untuk mengetahui presentase pengaruh dari variabel bebas terhadap variabel terikat pada penelitian ini.

\section{HASIL PENELITIAN}

Dari segi pembangunan suatu daerah, perkembangan suatu wilayah tidak terlepas dari kestabilan wilayah, karena jika kestabilan wilayah tidak baik maka suatu wilayah tidak dapat berkembang. Sehingga diketahui bahwa pengembangan bidang persatuan nasional dan politik adalah salah satu aspek pengembangan negara, dan tujuannya untuk memperkuat persatuan dan kesatuan peraturan dalam kerangka Negara Kesatuan Republik 
Indonesia berdasarkan nilai-nilai mulia. dari Pancasila dan "UUD 1945". Ketika melaksanakan rencana dan kegiatan di satu sektor, keadaan dan kebijakan harus dirumuskan dengan hati-hati, akurat dan akurat agar perencanaan berkelanjutan yang direncanakan dapat dilaksanakan.

Merujuk pada Undang-Undang Pemerintah Daerah Nomor 23 Tahun 2014, Voivode merupakan perwakilan pemerintah pusat di daerah dan menjalankan fungsi penyelenggaraan pemerintahan di daerah, OPD yang mematuhi tata kelola umum adalah lembaga negara dan entitas politik. Mereka juga berpartisipasi dalam pelaksanaan tugas secara absolut dan simultan dalam proses stok. Sulawesi Selatan terletak di bagian selatan Sulawesi, ibukotanya Makassar terletak strategis di Indonesia Timur, menjadikan Sulawesi Selatan sebagai pusat pelayanan Indonesia Timur dan dunia. Badan Kesbangpol Provinsi Sulawesi Selatan yang beralamat di Kompleks Kantir Gubernur Sulawesi Selatan Jalan Urip Sumohardjo No. 269Panaikang Kota Makassar.

Menurut PERDA (peraturan Daerah) Prov. Sulawesi Selatan No.10 (2016), tentang Pembentukan dan Susunan Perangkat Daerah, maka Badan kesatuan bangsa dan Politik mempunyai tugas menyelenggarakan penyusunan dan pelaksanaan kebijakan daerah di bidang kesatuan bangsa dan politik berada pada aturan peralihan yang berdasarkan asas desentralisasi, dekonsentrasi dan tugas pembantuan. Badan Kesatuan Bangsa dan Politik sendiri yang terletak di Kompleks kantor Kantor Gubernur Provinsi Sulawesi Selatan yang ruangannya terdiri atas dua lantai yang bertepatan di gedung $\mathrm{H}$ bersebelahan dengan tempat parkir di sisi timur pintu masuk. Berikut visi dan misi Badan Kesatuan Bangsa dan Politik Provinsi Sulawesi Selatan. Visi : terwujudnya Masyarakat Madani yang demokratis, sejahtera dan berkarakter sebagai Simpul Jejaring Pembangunan sesuai nilai-nilai Budaya dan Etika Politik dalam kerangka NKRI berdasarkan Pancasila. Sedangkan misi : (a) Mengembangkan sistem politik yang adil dan demokrasi berdasarkan pancasila dan UUD 1945 serta meningkatkan kinerja kemandirian infrastruktur politik dalam kehidupan Berbangsa dan Bernegara. (b) Meningkatkan integritas, persatuan dan kesatuan bangsa serta kesadaran bela Negara. (c) Mengembangkan pengkajian masalah strategis daerah meliputi ideologi politik sosial ekonomi budaya dan keamanan. (d) Memantapkan 4 (empat) pilar kebangsaan sebagai simpul jejaring 
pembangunan karakter bangsa. (e) Mendorong penyelenggaraan pemilu yang adil dan demokratis. (f) Meningkatkan refosionalisme aparatur Kesbangpol menuju terwujudnya pelayanan prima. Lebih lanjut apabila kita menelaah kembali visi dan misi Kesbangpol, terlihat bahwa dalam meningkatkan kinerja kemandirian perlu diperhatikan penyediaan infrastruktur yang lebih baik berupa sumber daya manusia dan pelayanan.

Oleh karena itu, jika infrastruktur tersebut dikembangkan dan ditingkatkan, diharapkan dapat tercapai. Adapun tujuan yang ingin dicapai oleh Badan Kesbangpol Provinsi Sulawesi Selatan dalam kurun waktu 5 (lima) tahun yaitu : Mewujudkan Sulawesi Selatan yang aman, damai dan demokratis, dan meningkatnya Akuntabilitas Perangkat Daerah.

Kemudian sasaran untuk mencapai tujuan, maka ditetapkan hasil yang diharapkan yaitu Meningkatnya keamanan dan ketenteraman masyarakat, meningkatnya indeks demokrasi Indonesia di Sulawesi Selatan, meningkatnya akuntabilitas kinerja, perencanaan dan pengelolaan dan keuangan perangkat daerah. Dalam rangka mencapai tujuan dan sasaran yang telah dirumuskan diatas maka Badan Kesatuan Bangsa dan Politik Provinsi Sulawesi Selatan merumuskan dan menetapkan 10 program yaitu : (1) Program Pelayanan Administrasi Perkantoran, (2) Program Peningkatan Sarana dan Prasarana, (3) Program Perencanaan, Penganggaran dan Evaluasi Kinerja, (4) Program Peningkatan Disiplin dan Kapasitas Sumber Daya Aparatur, (5) Program Peningkatan Kewaspadaan Nasional, (6) Program Pemeliharaan Ketenteraman, Ketertiban dalam Masyarakat dan Pencegahan Tindak Kriminal, (7) Program Pengembangan dalam aspek Wawasan Kebangsaan, (8) Program Peningkatan aspek Ketahanan dalam sector Ekonomi, (9) Program Pendidikan Politik bagi Masyarakat dan Pelaksanaan pemilihan umum yang sesuai dengan peraturan, (10) Program Peningkatan Kesadaran dalam kegiatan bela negara.

Berdasarkan hasil penelitian yang dilakukan pada Badan Kesatuan Bangsa dan Politik Provinsi Sulawesi Selatan dengan cara menggunakan kuesioner pada responden sejumlah 48 orang, maka diperoleh sejumlah data. Rersponden yang ada diklasifikasikan berdasarakan jenis kelamin, usia, tingkat pendidikan hingga golongan kepegawaian yang dimiliki. Secara keseluruhan data yang diperoleh dalam penelitian ini akan diuraikan maka tahap selanjutnya akan dibahas data yang 
telah diuraikan dan menginterpretasikan data secara keseluruhan untuk masingmasing variabel penelitian dapat dilakukan setelah terlebih dahulu diklasifikasikan, yakni berdasarkan jawaban-jawaban dari para responden yang ada pada penelitian pada tabel berikut ini :

\section{Tabel 3}

Distribusi Frekuensi Jawaban Responden Variabel X

\begin{tabular}{cccc}
\hline Skor & Kategorisasi & F & $(\mathbf{\%})$ \\
\hline 5 & Sangat Setuju & 91 & $18.95 \%$ \\
4 & Setuju & 329 & $68.54 \%$ \\
3 & Kurang Setuju & 55 & $11.45 \%$ \\
2 & Tidak Setuju & 4 & $0.83 \%$ \\
1 & Sangat Tidak & 1 & $0.20 \%$ \\
\hline & Setuju & & $\mathbf{1 0 0 \%}$ \\
\hline
\end{tabular}

Sumber : Data Primer (Diolah 2020)

Berdasarkan dari tabel distribusi frekuensi dari jawaban setiap responden yang terdapat pada penelitian, pada angket variabel $\mathrm{X}$ (tingkat pendidikan), dapat diketahui bahwa frekuensi jawaban berkategori sangat setuju berjumlah 91 (18.95\%), kategori setuju berjumlah 329 (68.54\%), kategori kurang setuju berjumlah 55 (11.45\%), kategori tidak setuju berjumlah $4(0.83 \%)$, dan Frekuensi frekuensi jawaban responden yang berkategori sangat tidak setuju berjumlah 1 responden $(0.20 \%)$.

Berdasarkan tabel distribusi frekuensi jawaban responden pada angket variabel Y, dapat diketahui frekuensi jawaban berkategori sangat setuju berjumlah 138 (28.75\%), kategori setuju berjumlah 295 (61.45\%), kategori kurang setuju berjumlah 46 (9.58\%), kategori tidak setuju berjumlah 1 (0.20\%), dan Frekuensi frekuensi jawaban berkategori sangat tidak setuju berjumlah $0(0 \%)$.

\section{Tabel 3}

Distribusi Frekuensi Klasifikasi Jawaban Responden Variabel Y

\begin{tabular}{cccc}
\hline Skor & Kategorisasi & F & (\%) \\
\hline 5 & Sangat Setuju & 138 & $28.75 \%$ \\
4 & Setuju & 295 & $61.45 \%$ \\
3 & Kurang Setuju & 46 & $9.58 \%$ \\
2 & Tidak Setuju & 1 & $0.20 \%$ \\
1 & Sangat TIdak Setuju & 0 & $0 \%$ \\
\hline & Total & $\mathbf{4 8 0}$ & $\mathbf{1 0 0} \%$ \\
\hline
\end{tabular}

Sumber : Data Primer (Diolah 2020)

Kemudian dilaksanakan analisis statistik deskriptif untuk melihat gambaran dari data yang diteliti dan mengetahui deskripsi data pada variabel yang diteliti dengan melihat nilai maksimum, nilai minimum, nilai rata-rata (mean), dan nilai standar deviasi. Pada penelitian ini variabel bebas $\mathrm{X}$ adalah tingkat pendidikan dan variabel terikat $\mathrm{Y}$ adalah peningkatan kinerja pegawai. Berdasarkan statistik deskriptif variabel penelitian, dapat diketahui bahwa dari kedua variabel penelitian memiliki N 48 yang berarti terdapat 48 jawaban angket dimana variabel $\mathrm{X}$ tingkat pendidikan perolehan nilai minimum ialah 34 sedangkan nilai 
maksimum adalah 50 dengan rata-rata (mean) 40.71, dan nilai standar deviasin 3.837. Kemudian pada variabel $\mathrm{Y}$ peningkatan kinerja pegawai perolehan nilai minimum ialah 34 sedangkan nilai maksimum adalah 50 dengan rata-rata (mean) 41.90, dan nilai standar deviasi sebesar 4.153. Kemudian dilakukan uji validitas dan reabilitas untuk instrumen penelitian yang digunakan Validitas menunjukkan sejauh mana alat pengukur yang dipergunakan untuk mengukur apa yang diukur. Adapun caranya adalah dengan mengkorelasikan antara skor yang diperoleh pada masing-masing item pertanyaan dengan skor total individu. Pengujian validitas dilakukan dengan menggunakan aplikasi SPSS versi 22. Dalam penelitian ini pengujian validitas dilakukan terhadap 48 responden. Pengambilan keputusan berdasarkan nilai rhitung (Corrected Item - Total Correlation) rtabel sebesar 0.291 untuk df $(\mathrm{N}-2)=48-2=46 ; \alpha=0,05$.

Kriteria untuk pengambilan keputusan uji validitas jika perolehan nilai $r$ hitung $>r$ tabel, maka angket dinyatakan valid namun apabila $\mathrm{r}$ hitung $<\mathrm{r}$ tabel, maka angket dinyarakan tidak valid. Berdasarkan uji validitas diatas dari kedua angket variabel penelitian dapat diketahui, bahwa yang menjadi rujukan dalam pengambilan keputusan untuk uji validitas adalah nilai $r$ hitung lebih besar dari 0,291 yang merupakan nilai $\mathrm{r}$ tabel. Kemudian berdasarkan dengan hasil uji validitas dari masing-masing angket pada kedua variabel penelitian yaitu Tingkat pendidikan (X), dan Peningkatan kinerja pegawai (Y) disimpulkan bahwa seluruh butir angket pertanyaan bersifat valid karena $r$ hitung $>$ 0.291( $\mathrm{r}$ tabel). Penelitian ini lebih lanjut harus dilakukan uji reliabilitas untuk mengukur konsisten atau tidak angket dalam kuesioner dalam penelitian ini. Sebelum dilakukannya pengujian reliabilitas harus ada dasar pengambilan keputusan yaitu alpha sebesar 0,60. Variabel yang dianggap reliabel jika nilai variabel tersebut lebih besar dari $>0,60$ Berdasarkan uji reliabilitas diatas diketahui bahwa pada dasar pengambilan keputusan memenuhi syarat uji reliabilitas jika nilai Alpha Cronbach lebih besar dari 0.6 , maka butir angket kuesioner penelitian bersifat reliabel. Angket butir pertanyaan dari kedua variabel yaitu tingkat pendidikan (X) dan Kinerja Pegawai (Y) diketahui bahwa seluruh jawaban angket butir pernyataan bersifat reliabel, karena nilai Alpha Cronbach lebih besar dari > 0.6 .

Kemudian dilaksanakan uji pra syarat analisis dengan uji normalitas yang 
bertujuan untuk menguji apakah dalam model regresi, variabel residual memiliki distribusi normal. Penelitian ini menggunakan dua cara untuk mendeteksi apakah residual berdistribusi normal atau tidak, yakni dengan menggunakan grafik dan analisis statistik. Uji normalitas data dalam penelitian ini dilakukan dengan dua cara, yaitu analisis grafik dan uji statistik. Analisis grafik dilakukan dengan melihat grafik histogram dan grafik normal probability plot uji statistik dilakukan dengan Uji Kolmogorov-Smirnov. Dalam analisa grafik histogram, jika bentuk kurva memiliki kemiringan yang cenderung seimbang, baik pada sisi kiri maupun kanan dan kurva menyerupai lonceng (bell-shaped) yang hampir sempurna maka data dinyatakan terdistribusi normal. Uji pra syarat analisis berikutnya adalah Uji linearitas yang bertujuan untuk menguji apakah keterkaitan antara dua variabel yang bersifat linier. Perhitungan linearitas digunakan untuk mengetahui prediktor data peubah bebas berhubungan secara linier atau tidak dengan variabel terikat. Uji linearitas dilakukan dengan menggunakan analisis variansi terhadap garis regresi yang nantinya akan diperoleh nilai f hitung.

Variabel bebas atau dependen dalam penelitian ini adalah tingkat pendidikan yang dipahami sebagai suatu proses peningkatan jenjang pendidikan yang ditempuh seseorang sesuai dengan jenjang pendidikan yang diterimanya secara formal terkelola sistematis dan terorganisir. Kemudian variabel terikat atau independen dalam penelitian ini adalah peningkatan kinerja ialah gambaran dari meningkatnya pencapaian pelaksanaan suatu kegiatan, program dan kebijakan dalam mewujudkan sasaran atau tujuan yang tertuang secara strategis dalam organisasi. Berdasarkan hasil uji validitas dan reabilitas dengan dasar pengambilan keputusan jika nilai $r$ hitung lebih besar dari 0,284 yang merupakan nilai $r$ tabel (rincian terlampir, df $(\mathrm{N}-2)=48-2=46$; $\alpha=0,05)$.

Kemudian berdasarkan dengan hasil uji validitas dari butir angket pernyataan pada variabel penelitian dapat dipastikan bahwa seluruh butir angket kuesioner penelitian bersifat valid karena $\mathrm{r}$ hitung $>0.284$ ( $\mathrm{r}$ tabel). Selanjutnya pada uji reliabilitas dari variabel penelitian, data variabel penelitian telah memenuhi syarat karena nilai Alpha Cronbach dari hasil pengujian yang dilaksanakan lebih besar dari 0.6. Pengujian pra syarat analisis yang dilakukan pada penelitian ini dengan menggunakan uji normalitas dan linearitas. Diketahui pada uji normalitas 
Kolmogorov-Smirnov nilai signifikansi sig. (2-tailed) sebesar 0.184, yang dimana nilai tersebut lebih besar dari 0.05 , kemudian pada grafik histogram distribusi data kurva dan grafik normal propability plot mengasumsikan bahwa data variabel penelitian normal, sehingga dapat dipastikan bahwa data variabel penelitian terdistribusi secara normal.

Untuk uji linearitas dilakukan dengan menggunakan analisis variansi terhadap garis regresi yang nantinya akan diperoleh nilai $f$ hitung, dasar pengambilan keputusan jika nilai $F 1.008<2.11$ (f tabel= $\mathrm{df}$ deviation from linearity ; $\mathrm{df}$ within group $(10 ; 36))$ dan nilai signifikansi deviation from linearity 0.456 $>0.05$ dinyatakan data variabel pada penelitian ini linear. Setelah melalui tahapan uji validitas. reabilitas dan uji pra syarat analisis, barulah kemudian layak untuk dilakukan analisis regresi linear sederhana untuk mengetahui persamaan regresi antara variabel penelitian.

Diketahui persamaan regresi variabel ada penelitian ini adalah $\mathrm{Y}=\mathrm{a}+$ $\mathrm{bX}(\mathrm{Y}=20.331+0.530)$, yang mengandung arti bahwa setiap penambahan $1 \%$ nilai variabel $\mathrm{X}$, maka nilai dari variabel $\mathrm{Y}$ bertambah 0.530 dan nilai dari koefisien regresi tersebut bernilai positif sehingga diasumsikan pengaruh variabel adalah positif. Hipotesis yang terdapat pada penelitian ini ialah merupakan dugaan sementara yang ditetapkan oleh peneliti, oleh karena itu perlu dilakukannya pembuktian hipotesis untuk mengetahui kebenaran dari suatu dugaan.

Pengujian hipotesis dalam penelitian ini uji signifikansi parsial (uji t) dan analisis koefisien determinasi. Uji signifikansi regresi parsial (uji t), sebelum dijabarkan lebih lanjut terlebih dahulu diketahui harus diketahui nilai $t$ tabel yaitu $2.012(\mathrm{t}$ tabel $=\mathrm{t}(\mathrm{a} / 2 ; \mathrm{n}-\mathrm{k}-1)=\mathrm{t}(0.025$; 46)) yang digunakan sebagai pembanding dalam dasar pengamblan keutusan. Nilai Sig. variabel X (tingkat pendidikan) adalah $0.000<0.05$ dan nilai $\mathrm{t}$ hitung $3.807>\mathrm{t}$ tabel 2.012, Sehingga berdasarkan kedua asumsi tersebut maka dipastikan terdapat pengaruh variabel bebas (X) terhadap variabel terikat $(\mathrm{Y})$.

Setelah melalui tahapan uji validitas. reabilitas dan uji pra syarat analisis, barulah kemudian layak untuk dilakukan analisis regresi linear sederhana untuk mengetahui persamaan regresi antara variabel penelitian. Diketahui persamaan regresi variabel ada penelitian ini adalah $\mathrm{Y}=\mathrm{a}+\mathrm{bX}(\mathrm{Y}=20.331+$ 0.530 ), yang mengandung arti bahwa setiap penambahan $1 \%$ nilai variabel $\mathrm{X}$, 
maka nilai dari variabel $\mathrm{Y}$ bertambah 0.530 dan nilai dari koefisien regresi tersebut bernilai positif sehingga diasumsikan pengaruh variabel adalah positif.

Hipotesis yang terdapat pada penelitian ini ialah merupakan dugaan sementara yang ditetapkan oleh peneliti, oleh karena itu perlu dilakukannya pembuktian hipotesis untuk mengetahui kebenaran dari suatu dugaan. Pengujian hipotesis dalam penelitian ini uji signifikansi parsial (uji t) dan analisis koefisien determinasi. Uji signifikansi regresi parsial (uji t), sebelum dijabarkan lebih lanjut terlebih dahulu diketahui harus diketahui nilai $\mathrm{t}$ tabel yaitu $2.012(\mathrm{t}$ tabel $=$ $\mathrm{t}(\mathrm{a} / 2 ; \mathrm{n}-\mathrm{k}-1)=\mathrm{t}(0.025 ; 46))$ yang digunakan sebagai pembanding dalam dasar pengamblan keutusan. Nilai Sig. variabel X (tingkat pendidikan) adalah $0.000<0.05$ dan nilai $\mathrm{t}$ hitung $3.807>\mathrm{t}$ tabel 2.012, Sehingga berdasarkan kedua asumsi tersebut maka dipastikan terdapat pengaruh variabel bebas (X) terhadap variabel terikat $(\mathrm{Y})$.

Selanjutnya untuk mengukur seberapa jauh kemampuan variabel independen dalam menginterpretasikan variabel dependen dilakukan analisis koefisien determinasi R2, dimana nilai Adjusted $R$ Square adalah 0.240 atau berdasarkan dengan kaidah perhitungan pada tahap analisis ini apabila nilai tersebut dipersentasekan menjadi $24 \%$. Nilai koefisien determinasi tersebut mengandung arti bahwa variabel terikat (peningkatan kinerja) dapat diinterpretasikan (digambarkan) oleh variabel tingkat pendidikan sebesar $24 \%$, sedangkan 76\% (100\% - 24\%) dipengaruhi oleh sebab-sebab lain di luar variabel independen yang terdapat pada penelitian ini atau dalam pengertian dan arti lain dinyatakan bahwa nilai pengaruh dari variabel tingkat pendidikan $(\mathrm{X})$ terhadap variabel peningkatan kinerja $(\mathrm{Y})$ ialah $24 \%$.

\section{PEMBAHASAN}

Berdasarkan hasil penjabaran dari pengujian dan analisis yang dilakukan, penelitian ini dengan fokus kajian pengaruh tingkat pendidikan terhadap peningkatan kinerja Pegawai Badan Kesatuan Bangsa dan Politik Pemerintah Provinsi Sulawesi Selatan, diajukan hipotesis penelitian sebagai berikut :

Hipotesis nihil (Ho) : Tidak terdapat pengaruh yang positif dan signifikan antara tingkat pendidikan terhadap peningkatan kinerja Pegawai Badan Kesatuan Bangsa dan Politik Pemerintah Provinsi Sulawesi Selatan. Hipotesis 
alternatif (Ha) : Terdapat pengaruh yang positif dan signifikan antara tingkat pendidikan terhadap peningkatan kinerja Pegawai Badan Kesatuan Bangsa dan Politik Pemerintah Provinsi Sulawesi Selatan. Setelah melalui tahapan uji pra syarat anaisis diatas kemudian dilanjutkan dengan analisis regresi linear sederhana dimana dieroleh persamaan regresi $\mathrm{Y}=\mathrm{a}+$ bX $(Y=20.331+0.530)$. Nilai Konstanta ialah 20.331, mengandung arti bahwa nilai konsistensi dari variabel Y adalah 20.331. Koefisien regresi variabel $\mathrm{X}$ ialah 0.530 , diartikan setiap penambahan $1 \%$ nilai variabel $\mathrm{X}$, maka nilai dari variabel $\mathrm{Y}$ bertambah 0.530. dilanutkan dengan tahap pengujian hipotesis dengan uji signifikansi regresi aprsial (uji-t) dan analisis koefisien dterminasi. Uji signifikansi regresi parsial (uji t) bertujuan untuk mengetahui besarnya pengaruh parsial variabel independen (bebas) terhadap variabel dependen (terikat) dengan dasar pengambilan keputusan jika $t_{\text {hitung }}>t_{\text {tabel }}$ dan nilai Sig. $<0.05$ maka secara parsial variabel independen berpengaruh signifikan terhadap variabel dependen yang ada.

Koefisien determinasi adalah pengujian untuk mengukur seberapa jauh kemampuan model dalam menerangkan variabel-variabel dependen. Nilai koefisien determinasi adalah antara nol dan satu. Nilai $\mathrm{R}^{2}$ yang kecil berarti kemampuan variabel independen dalam menjelaskan variasi variabel dependen amat terbatas. Nilai yang mendekati satu berarti variabelvariabel independen memberikan hampir semua informasi yang dibutuhkan untuk memprediksi variasi variabel dependen. Uji signifikansi regresi parsial (uji t) diatas sebelum dijabarkan lebih lanjut terlebih dahulu diketahui nilai $\mathrm{t}$ tabel yaitu 2.012 yang diperoleh dari distribusi nilai t tabel dimana 2.012 diperoleh dari : $\mathrm{t}$ tabel $=\mathrm{t}$ $(\mathrm{a} / 2 ; \mathrm{n}-\mathrm{k}-1)=\mathrm{t}(0.025 ; 46)$. Kemudian diiketahui dari hasil uji signifikansi regresi parsial (uji t) nilai Sig. variabel X (tingkat pendidikan) adala $0.000<0.05$ dan nilai $\mathrm{t}$ hitung $3.807>\mathrm{t}$ tabel 2.012, Sehingga berdasarkan kedua asumsi tersebut maka dipastikan terdapat pengaruh variabel bebas (X) terhadap variabel terikat $(\mathrm{Y})$. Hasil analisis koefisien determinasi $\mathrm{R}^{2}$, diketahui bahwa nilai $R$ Square ialah 0.240 atau berdasarkan dengan ketentuan perhitungan dalam pengujian koefisien determinasi $\left(\mathrm{R}^{2}\right)$ apabila dipersentasekan menjadi $24 \%$. Nilai $R$ Square atau nilai koefisien determinasi mengandung arti bahwa variabel peningkatan kinerja pegawai (Variabel Y) dapat dipengaruhi oleh variabel tingkat pendidikan sebesar $24 \%$, sedangkan $76 \%(100 \%-24 \%)$ 
dipengaruhi oleh sebab-sebab lain di luar variabel independen yang terdapat pada penelitian ini. Kemudian berdasarkan penelitian ini yang bertujuan untuk mengetahui apakah tingkat pendidikan berpengaruh terhadap peningkatan kinerja pegawai Badan Kesatuan Bangsa dan Politik Provinsi Sulawesi Selatan. Dalam penelitian ini, dilakukan pengujian instrumen penelitian yaitu uji validitas dan reabilitas yang dilanjutkan dengan pengujian pra syarat analisis (uji normalitas dan linearitas). Setelah melakukan serangkaian pengujian tersebut, maka layak dilanjutkan dilakukan analisis regresi linear sederhana dengan pengujian hipotesis uji signifikansi parsial (uji t) dan analisis koefisien determinasi R2.

Variabel bebas atau dependen dalam penelitian ini adalah tingkat pendidikan yang dipahami sebagai suatu proses peningkatan jenjang pendidikan yang ditempuh seseorang sesuai dengan jenjang pendidikan yang diterimanya secara formal terkelola sistematis dan terorganisir. Kemudian variabel terikat atau independen dalam penelitian ini adalah peningkatan kinerja ialah gambaran dari meningkatnya pencapaian pelaksanaan suatu kegiatan, program dan kebijakan dalam mewujudkan sasaran atau tujuan yang tertuang secara strategis dalam organisasi. Berdasarkan hasil uji validitas dan reabilitas dengan dasar pengambilan keputusan jika nilai $\mathrm{r}$ hitung lebih besar dari 0,284 yang merupakan nilai $\mathrm{r}$ tabel (rincian terlampir, df $(\mathrm{N}-2)=48-2=46$; $\alpha=0,05)$. Kemudian berdasarkan dengan hasil uji validitas dari butir angket pernyataan pada variabel penelitian dapat dipastikan bahwa seluruh butir angket kuesioner penelitian bersifat valid karena $\mathrm{r}$ hitung $>0.284$ ( $\mathrm{r}$ tabel). Selanjutnya pada uji reliabilitas dari variabel penelitian, data variabel penelitian telah memenuhi syarat karena nilai Alpha Cronbach dari hasil pengujian yang dilaksanakan lebih besar dari 0,6 . Pengujian pra syarat analisis yang dilakukan pada penelitian ini dengan menggunakan uji normalitas dan linearitas.

Diketahui pada uji normalitas Kolmogorov-Smirnov nilai signifikansi sig. (2-tailed) sebesar 0.184, yang dimana nilai tersebut lebih besar dari 0.05, kemudian pada grafik histogram distribusi data kurva dan grafik normal propability plot mengasumsikan bahwa data variabel penelitian normal, sehingga dapat dipastikan bahwa data variabel penelitian terdistribusi secara normal. Untuk uji linearitas dilakukan dengan menggunakan analisis variansi terhadap garis regresi yang nantinya akan diperoleh nilai $\mathrm{f}$ 
hitung, dasar pengambilan keputusan jika nilai F $1.008<2.11$ ( $\mathrm{f}$ tabel $=d f$ deviation from linearity ; df within group $(10 ; 36))$ dan nilai signifikansi deviation from linearity $0.456>0.05$ dinyatakan data variabel pada penelitian ini linear. Setelah melalui tahapan uji validitas. reabilitas dan uji pra syarat analisis, barulah kemudian layak untuk dilakukan analisis regresi linear sederhana untuk mengetahui persamaan regresi antara variabel penelitian. Diketahui persamaan regresi variabel ada penelitian ini adalah $\mathrm{Y}=\mathrm{a}+$ $\mathrm{bX}(\mathrm{Y}=20.331+0.530)$, yang mengandung arti bahwa setiap penambahan $1 \%$ nilai variabel $\mathrm{X}$, maka nilai dari variabel $\mathrm{Y}$ bertambah 0.530 dan nilai dari koefisien regresi tersebut bernilai positif sehingga diasumsikan pengaruh variabel adalah positif.

Hipotesis yang terdapat pada penelitian ini ialah merupakan dugaan sementara yang ditetapkan oleh peneliti, oleh karena itu perlu dilakukannya pembuktian hipotesis untuk mengetahui kebenaran dari suatu dugaan. Pengujian hipotesis dalam penelitian ini uji signifikansi parsial (uji t) dan analisis koefisien determinasi. Uji signifikansi regresi parsial (uji t), sebelum dijabarkan lebih lanjut terlebih dahulu diketahui harus diketahui nilai $\mathrm{t}$ tabel yaitu $2.012(\mathrm{t}$ tabel $=$ $\mathrm{t}(\mathrm{a} / 2 ; \mathrm{n}-\mathrm{k}-1)=\mathrm{t}(0.025 ; 46))$ yang digunakan sebagai pembanding dalam dasar pengamblan keutusan. Nilai Sig. variabel $\mathrm{X}$ (tingkat pendidikan) adalah $0.000<0.05$ dan nilai $\mathrm{t}$ hitung $3.807>\mathrm{t}$ tabel 2.012, Sehingga berdasarkan kedua asumsi tersebut maka dipastikan terdapat pengaruh variabel bebas (X) terhadap variabel terikat (Y). Selanjutnya untuk mengukur seberapa jauh kemampuan variabel independen dalam menginterpretasikan variabel dependen dilakukan analisis koefisien determinasi R2, dimana nilai Adjusted $R$ Square adalah 0.240 atau berdasarkan dengan kaidah perhitungan pada tahap analisis ini apabila nilai tersebut dipersentasekan menjadi 24\%. Nilai koefisien determinasi tersebut mengandung arti bahwa variabel terikat (peningkatan kinerja) dapat diinterpretasikan (digambarkan) oleh variabel tingkat pendidikan sebesar $24 \%$, sedangkan $76 \%(100 \%-24 \%)$ dipengaruhi oleh sebab-sebab lain di luar variabel independen yang terdapat pada penelitian ini atau dalam pengertian dan arti lain dinyatakan bahwa nilai pengaruh dari variabel tingkat pendidikan $(\mathrm{X})$ terhadap variabel peningkatan kinerja $(\mathrm{Y})$ ialah 24\%. Berdasarkan dari hasil pengujian dan interpretasi, analisis regresi linear sederhana pada penelitian ini hingga 
pengujian hipotesis dengan melakukan uji signifikansi parsial (uji t) dan analisis koefisien determinasi, dapat ditarik kesimpulkan bahwa terdapat pengaruh positif dan signifikan antara tingkat pendidikan terhadap peningkatan kinerja Pegawai Badan Kesatuan Bangsa dan Politik Pemerintah Provinsi Sulawesi Selatan. Hal tersebut dibuktikan dengan persamaan regresi dan hasil pengujian dari variabel bebas $(\mathrm{X})$ yang menunjukkan nilai 0.240 Adjusted $R$ Square atau dapat diinterpretasikan menjadi $24 \%$ dengan nilai t hitung $3.807>\mathrm{t}$ tabel 2.012, yang di dalam dasar pengambilan keputusan nilai tersebut dinyatakan positif dan signifikan berpengaruh terhadap variabel terikat $(\mathrm{Y})$.

Kemudian berdasarkan penarikan kesimpulan dari analisa dan pengujian tersebut maka dapat dipastikan bahwa pada hipotesis penelitian yang diajukan diambil keputusan Ho ditolak dan $\mathrm{Ha}$ diterima, yang menegaskan bahwa tingkat pendidikan adalah sebuah aspek yang penting dan krusial dalam peningkatan kinerja dalam melaksanakan tugas dan pekerjaan.

Tingkat pendidikan berpengaruh positif dan signifikan terhadap peningkatan kinerja jajaran pegawai Badan Kesabangpol Provinsi Sulawesi Selatan, hal ini wajar dan sejalan dengan teori
Robbins dalam Wibowo (2013) yang menunjukkan dampak terhadap pegawai.

\section{Gambar 1} Grafik Penerimaan Hipotesis

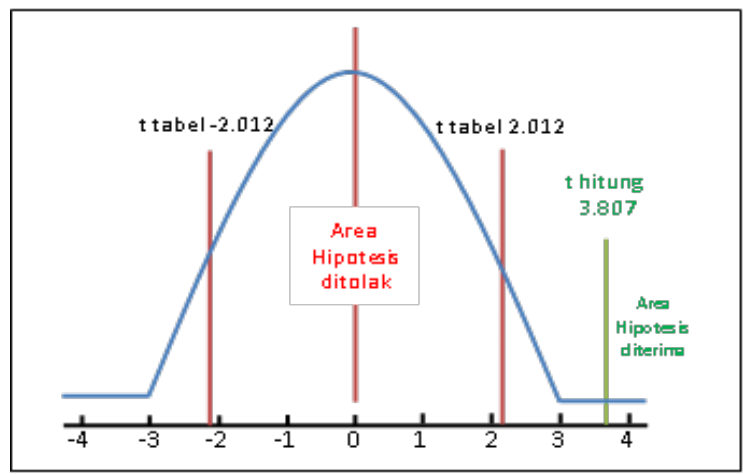

Sumber : Data Primer (Diolah 2020)

Faktor kinerja dipengaruhi oleh banyak faktor, termasuk perilaku dasar ASEK pribadi, termasuk karakteristik biografi, kemampuan dan kemampuan belajar. Penjelasan ini menunjukkan bahwa tingkat pendidikan adalah salah satu faktor penting untuk melakukan kinerja kerja yang lebih baik. Kemudian didukung oleh pandangan Sikula (2011) yang menegaskan bahwa tingkat pendidikan seseorang dapat meningkatkan daya saing organisasi dan dapat meningkatkan, dan mendukung kinerja perusahaan secara berkelanjutan. Kemudian Notoatmodjo (2003) mengemukakan bahwa Tingkat pendidikan tinggi seorang karyawan akan mempengaruhi kemampuannya untuk mencapai kinerja terbaik, dan menerima pendidikan dalam suatu organisasi adalah 
proses mengembangkan kemampuan organisasi, oleh karena itu perguruan tinggi masyarakat merupakan sumber daya manusia yang dapat menjadi sumber daya manusia. diharapkan Kemampuannya semakin tinggi dan lebih tinggi. Hasil dari penelitian ini, didukung oleh kajian yang dilakukan oleh Marlia (2017) yang juga menunjukkan bahwa pendidikan berpengaruh positif dan signifikan terhadap kinerja karyawan. Koefisien determinasi dihitung menjadi 31,3\%, sedangkan sisanya terpengaruh berdasarkan faktor lain. Kemudian penelitian dilakukan oleh Situmeang (2017) yang mempelajari tentang Dampak pendidikan dan pengalaman kerja terhadap kinerja karyawan. Diantaranya, hasil penelitian mereka mengandung beberapa variabel independen yang berpengaruh positif dan penting terhadap kinerja karyawan. dipengaruhi oleh kinerja karyawan. Pendidikan, meskipun mendapat dukungan lain. Selain itu, tergantung pada beberapa teori dan hasil penelitian terkait, dapat disimpulkan bahwa tingkat pendidikan sangat penting karena berdampak pada kinerja, terutama untuk meningkatkan kinerja organisasi. Selain itu, pada organisasi sektor publik yang menuntut ASN untuk selalu menjaga integritas dalam melaksanakan tugasnya,
ASN menggunakan pengetahuan dan keterampilan yang telah diakui oleh tingkat pendidikan untuk menjalankan tugasnya sesuai dengan tugasnya. lulus. Tentunya diperlukan upaya lain untuk mengembangkan sumber daya manusia organisasi, tidak hanya bertumpu pada jenjang pendidikan, tetapi juga dengan pengembangan kemampuan kerja dan profesionalisme.

Gambar 2 Interpretasi Presentasi

\section{Pengaruh Tingkat Pendidikan terhadap} Peningkatan Kinerja

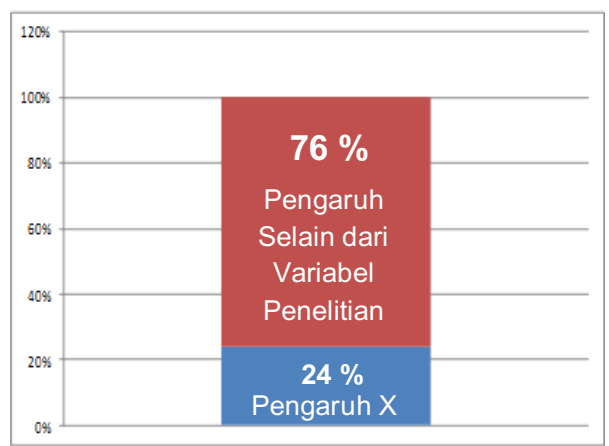

Sumber : Data Primer (Diolah 2020)

\section{KESIMPULAN}

Peningkatan jenjang pendidikan pegawai berpengaruh positif terhadap peningkatan kinerja pegawai pada Badan Kesbangpol Prov. Sulawesi Selatan. Pada pengujian hipotesis, variabel tingkat pendidikan adalah $0,000<0,05$, dan nilai $\mathrm{t}$ sebesar 3,807> T Tabel 2012, maka dapat ditarik kesimpulan dari hipotesis ini: variabel bebas (x) dan variabel terikat $(\mathrm{Y})$, 
maka koefisien determinasi adalah 0,240 atau persentase dua puluh empat persen. Nilai tersebut berarti bahwa tingkat $24 \%$ variabel pendidikan dapat digunakan untuk menjelaskan (menjelaskan) variabel terikat (peningkatan kinerja), sedangkan variabel yang dipengaruhi oleh penyebab lain dari variabel penelitian adalah 76\% (100\% $24 \%)$.

Pengaruh positif dan signifikan dari peningkatan kinerja yang diprediksi oleh tingkat pendidikan karyawan adalah wajar dan sesuai dengan teori Robbins dalam Wibowo (2013) yang menunjukkan bahwa Faktor yang mempengaruhi pertumbuhan kinerja karyawan dipengaruhi oleh angka. Faktor-faktor tersebut meliputi aspek dasar perilaku pribadi, meliputi karakteristik biografi, kemampuan dan kemampuan belajar. Penjelasan tersebut Ini menunjukkan bahwa pendidikan adalah salah satu faktor penting untuk melakukan kinerja kerja yang lebih baik. Kemudian mendapat dukungan dari Sikula (2011) dan Notoatmodjo (2003) yang mengemukakan bahwa pendidikan tinggi karyawan akan mempengaruhi kinerja terbaiknya Pendidikan dalam organisasi adalah proses pembinaan yang berkelanjutan. dan kemampuan giat diharapkan organisasi terkait, oleh karena itu semakin tinggi latar belakang pendidikan masyarakat maka semakin tinggi pula kemampuan sumber daya manusia yang diharapkan. Namun upaya lain untuk mengembangkan sumber daya manusia juga membutuhkan keterampilan intelektual yang diperoleh dari tingkat pendidikan, tidak hanya bertumpu pada tingkat pendidikan, tetapi juga dengan pengembangan kemampuan kerja dan profesional.

\section{REFERENSI}

Dewi, Desak Ketut Ratna, Suwendra, Wayan, dan Yulianthini, Nyoman.. $2016 \quad$ Pengaruh

Tingkat Pendidikan dan Motivasi Kerja terhadap Kinerja Karyawan, e- Journal Bisma : Universitas Pendidikan Ganesha. Vol.02 No.02 Agustus.

Fathoni, Abdurrahmat. 2006. Organisasi dan Manajemen Sumber Daya Manusia. Jakarta : PT. Rineka Cipta

Hasibuan, Malayu. 2007. Manajemen Sumber Daya Manusia (Cetakan Ketiga). Jakarta : Bumi Aksara.

Ishak, Arep \& Tanjung, Hendri. 2003. Manajemen Sumber Daya Manusia. Jakarta : Universitas Trisakti

Mangkunegara, Anwar Prabu. 2006. Manajemen Sumber Daya Perusahaan. Bandung : PT. Remaja Rosda Karya

Marlia, Elfina. 2017. Pengaruh Pendidikan Terhadap Kinerja Karyawan (PT.Inti Persero) Bandung. Skripsi 
Bandung : Universitas

Widyatama Bandung

Nasution, Beti. 2010. Manajemen Sumber Daya Manusia

Strategis. Medan : Fisip USU Pres.

Notoatmodjo, $\quad 2003$. Pengembangan Sumber Daya

Manusia. Jakarta : Rineka Cipta Sikula.

Andrew, E. 2011. Manajemen Sumber Daya Manusia. Bandung : Erlangga

Situmeang, Rosinta Romauli, 2017. Pengaruh Pengawasan dan
Pengalaman Kerja Terhadap Kinerja Karyawan pada PT. Mitra Karya Anugrah. Jurnal AJIE : Universitas Prima Indonesia Medan. Vol. $02 \quad$ No.02, Mei

Sudarmanto. 2009. Kinerja dan Pengembangan Sumber Daya Manusia. Yogyakarta : Pustaka Pelajar.

Supratikno, Hendrawan. 2006. Manajemen Kinerja untuk Menciptakan Keunggulan Bersaing.Yogyakarta: Raha Ilmu.

Wibowo. 2013. Manajemen Kinerja. Jakarta : Rajawali Pres. 